\title{
沿岸扇状地小流域における硝酸性窒素流出過程
}

\author{
齋藤 光代 ${ }^{1)} \cdot$ 小野寺真-2) -竹井 務 ${ }^{1)}$
}

\section{Nitrate transport process in a small coastal alluvial fan catchment}

\author{
Mitsuyo SAITO"), Shin-ichi ONODERA ${ }^{2)}$ and Tsutomu TAKEI ${ }^{1)}$
}

\begin{abstract}
In order to demonstrate the nitrate transport process from land to the sea, variations in the $\mathrm{NO}_{3}^{-}-\mathrm{N}$ flux of river water were investigated, and the $\mathrm{NO}_{3}^{-}-\mathrm{N}$ flux of groundwater was estimated in a small coastal alluvial fan catchment covered by orange groves. The results are summarized as follows: 1) In the base-flow period, the $\mathrm{NO}_{3}^{-}-\mathrm{N}$ flux of river water decreased from the midstream to the downstream area with the deduction in runoff; 2) At the peak of a storm event with $11 \mathrm{~mm}$ of total rainfall, the $\mathrm{NO}_{3}{ }^{-}-\mathrm{N}$ flux increased up to about 16 times that in the base-flow period. The total discharge of $\mathrm{NO}_{3}{ }^{-} \mathrm{N}$ during that event was estimated to be equal to that of 4 days during the base-flow period ; 3) The $\mathrm{NO}_{3}-\mathrm{N}$ concentration in groundwater was more than $20 \mathrm{mg} \mathrm{L}^{-1}$ at the midstream area, whereas it had declined to less than $2.0 \mathrm{mg} \mathrm{L}^{-1}$ in the downstream area. Based on these results, we estimated the $\mathrm{NO}_{3}^{-}-\mathrm{N}_{\text {discharge }}$ by groundwater to the sea to be about $2.4 \%$ of the annual nitrogen input from fertilizer application, suggesting that $\mathrm{NO}_{3}^{-}-\mathrm{N}$ was removed from groundwater by denitrification in the downstream area.
\end{abstract}

Key words : nitrate, transport process, alluvial fan, river water, groundwater

\section{摘 要}

本研究では，硝酸性窒素 $\left(\mathrm{NO}_{3}{ }^{-}-\mathrm{N}\right)$ の陸域から海洋への流出過程を明らかにするため，沿岸扇状地の 果樹園の広く分布する小流域において，洪水流出時を含めた河川の上流から下流への $\mathrm{NO}_{3}{ }^{-}-\mathrm{N}$ 負荷量の変 動を確認するとともに，地下水としての $\mathrm{NO}_{3}{ }^{-}-\mathrm{N}$ 流出量の見積もりを行った。その結果，以下のことが明 らかになった。1) 平水時には, 河川の中流から下流に向かって河川流量が減少し, それにともない $\mathrm{NO}_{3}{ }^{-} \mathrm{N}$ 負荷量も減少した。2) 総雨量 $11 \mathrm{~mm}$ の降雨イベント時には，河川流量の増加にともない $\mathrm{NO}_{3}{ }^{-}-\mathrm{N}_{\text {負荷量が }}$ 増加し, 流量のピーク時には平水時の約 16 倍に達した。また，イベント全体を通しては, 河川からの $\mathrm{NO}_{3}{ }^{-}-\mathrm{N}$ 流出量が，平水時約 4 日分の量に相当した。3）地下水の $\mathrm{NO}_{3}{ }^{-}-\mathrm{N}$ 濃度は中流域で $20 \mathrm{mg} \mathrm{L}^{-1}$ を回 る高濃度を示したが, 最下流域では $2.0 \mathrm{mg} \mathrm{L}^{-1}$ 以下に減少した。その結果, 地下水としての海洋への $\mathrm{NO}_{3}{ }^{-}-\mathrm{N}$ 流出量は，施肥としての年間窒素インプット量の約 $2.4 \%$ 程度であると推定された。また，下流域に㧍け る $\mathrm{NO}_{3}{ }^{-}-\mathrm{N}$ の消失は脱窒反応によるものである可能性が示唆された。 キーワード：硝酸性窒素, 流出過程, 河川水, 地下水

1) 広島大学大学院生物圈科学研究科 T739-8521 東広島市鏡山 1-7-1. Graduate School of Biosphere Sciences, Hiroshima University, 1-7-1 Kagamiyama, Higashi-Hiroshima 739-8521, Japan (E-mail:misaito@hiroshima-u.ac.jp)

2) 広島大学総合科学部 干 739-8521 東広島市鏡山 1-7-1. Faculty of Integrated Arts and Sciences, Hiroshima University, 1-7-1 Kagamiyama Higashi-Hiroshima 739-8521, Japan 


\section{はじめに}

閉鎖性海域の富栄養化は依然として解決されない世界 的な環境問題の一つであり，その原因となる陸域から海 洋への栄養塩負荷が問題視されている。その一方で, 近 年多くの農業地域では, 過剩施肥にともなう地表水およ び地下水の硝酸性窒素 $\left(\mathrm{NO}_{3}{ }^{-}-\mathrm{N}\right)$ 污染が顥在化しておう (鶴巻, 1992; Burt et al., 1993; 田瀬, 2003), 海洋への窒 素負荷の評価および軽減が求められている。従来から, 農業地域に扝ける窒素流出の定量化に関する研究は多く 行われてきた（海老瀬, 1985 ; 宗宮, 1993; 竹内，1995)。 しかし, 河川水と地下水といら流出経路, 洪水流出時を 含めた窒素負荷量の時間的・空間的変化および窒素循環 に関連する化学プロセスを考慮した陸域から海洋への窒 素流出過程については，これまで十分に明らかにされて きたとはいえない。地下水に関しては，近年，多くの研 究において地下水による栄盖塩流出が海洋環境に大きな 影響を及ぼすことが明らかにされている（Marsh，1977； Johannes, 1980; D' Elia et al., 1981; Capone and Bautista, 1985; McLachlan and lllenberger, 1986; Simmons, 1992)。また, Zektser and Loaiciga（1993）は，世界の大規模河川流域に おいて地下水による栄養塩流出量が河川からの流出量の $50 \%$ 以上に及ぶと推定しており, 海洋への栄養塩流出を 評価する際の地下水の重要性を指摘している。しかし, 農業活動の影響の強い特定の河川流域において河川水と 地下水双方の影響を考慮し, 窒素流出を評価した例は少 なく, 特に, 河川水の地下水涵養や地下水の河川流出に ともなう流域内での窒素流出経路の変化に関しては, 十 分に明らかにされていない。また，洪水流出時は一般に 河川流量の増加にともない基底流出時と比較して窒素流 出量は増加すると想定される（中曾根・中村，1984）が, 流出経路の変化に関してはあまり言及されていない。

一方, 化学過程に関しては, 近年地下水中で脱窒反応 による $\mathrm{NO}_{3}{ }^{-}-\mathrm{N}$ の消失が起こるという事例がいくつか報 告されており (Postma et al., 1991; Böhlke and Denver, 1995; 石塚 - 小野寺, 1997), Howard (1985) やUchiyama et al. （2000）などは, 沿岸域の地下水中において地下水流動に ともない脱窒反忘が起こる現象を明らかにしている。し かし, 従来の研究では窒素浄化機能を考慮に入れた窒素 流出量の評価は十分に行われていない。

本研究では, 沿岸扇状地小流域に执いて, 海洋への $\mathrm{NO}_{3}{ }^{-}-\mathrm{N}$ 流出過程を明らかにすることを目的とする。特 に, 基底流出時および洪水流出時にお汀る河川の上流か ら下流への $\mathrm{NO}_{3}{ }^{-}-\mathrm{N}$ 負荷量の変動を確認し, $\mathrm{NO}_{3}{ }^{-}-\mathrm{N}$ の流
出経路を明らかにするとともに，净化機能を考慮したう えで地下水としての $\mathrm{NO}_{3}{ }^{-}-\mathrm{N}$ 流出量の見積もりを行った。

\section{調査地域概要と方法}

\section{試験流域}

試験流域は，瀬戸内海の島嶼の一つである広島県豊田 郡瀬戸田町（生口島）に位置する（Fig. 1)。閉鎖海域であ る瀬戸内海の富栄盖化は, 日本を代表する環境問題の一 つであり，1970 年代を境に改善に向かっているものの, 現在も完全な解決には至っていない。瀬戸内海沿岸地域 は, 温暖かつ少雨型の気候であり（生口島で年平均気温 $15.6^{\circ} \mathrm{C}$, 年平均降水量 $1100 \mathrm{~mm}$ ), 花崗岩が広く分布寸る とともに，柑橘系の果樹園栽培が盛んである。生口島に おいては，主にみかんを中心とした果樹園が島全体に一 様に分布し, 島の総面積の約 40\%を占める(谷口ら, 1978; Nakagoshi and Ohta, 1992 ; 池上・中越, 1995)。しかし, 近 年では施肥などにともなう河川水及び地下水の $\mathrm{NO}_{3}{ }^{-}-\mathrm{N}$ 濃度の上昇が報告されており（熊沢，1994）, 瀬戸内海の 富栄養化問題とも関連して, 海洋への窒素負荷が危惧さ れている。

試験流域の基盤地質は花崗岩から成り, 流域面積は $44.3 \mathrm{ha}$, 流下距離は $1.8 \mathrm{~km}$ である。また, 急勾配な山地 河川地形を呈し，流域の中流から下流にかけては明暸な 扇状地地形がみられ，みかんの果樹園が広く分布してお り，水田の分布はほとんどみられない。また，中流域か ら下流では民家が点在するが，下水道の整備はなされて いない。

\section{現地調査および水質分析}

試験流域では，河川水及び地下水の調查を行った。試 験河川では, 流域の上流から下流にかけて約 $100 \sim 300 \mathrm{~m}$ おきに計 5 箇所の採水地点 $(\mathrm{A} \sim \mathrm{E})$ を設定し，河川水の 採水と流量測定を行った（Fig. 1，Table 1)。河川流量の測 定は，すべて浮子法 (Hewlett, 1964) で行った。平水時 (Base-flow period) は，2002年6月，10月，12月の計 3 回 調査を行った。また，洪水流出時の調查として，2002年 7月9〜10日にかけて発生した総雨量 $11 \mathrm{~mm}$ の降雨イベ ント時（Storm-flow period）に集中観測を行い，1〜3時 間扝きに採水と流量観測を計 6 回行った。ただし，降雨 イベント時は採水地点を $\mathrm{A}, \mathrm{C}, \mathrm{D}, \mathrm{E}$ の 4 地点に限定し, 採水地点間を移動しながら観測を行った。そのため, 1 回 の観測につき最上流 (A) と最下流（E）の地点では観測 時間に約 $10 \sim 15$ 分の差があった。地下水については, 


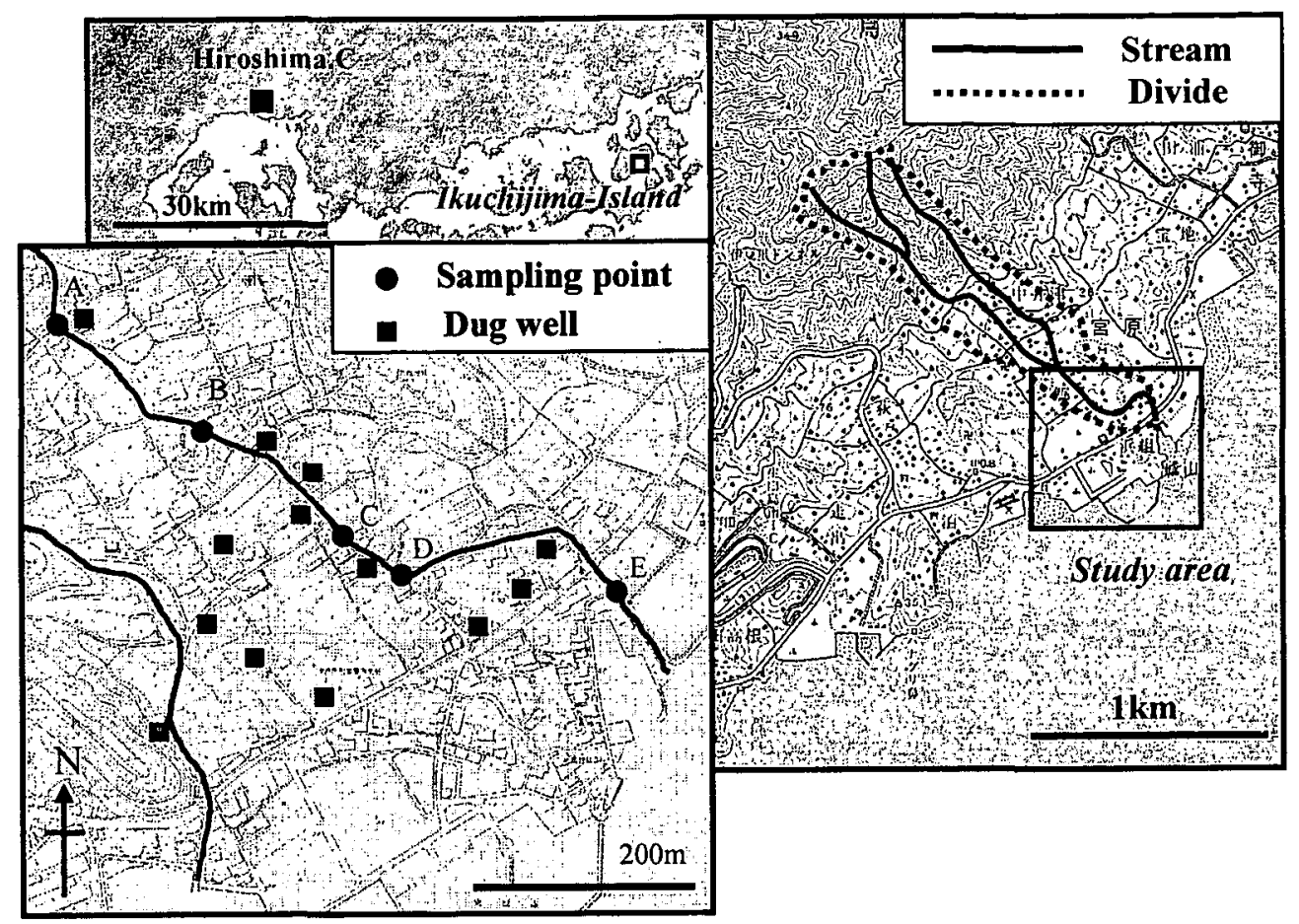

Fig. 1. Location of study area and sampling points in the study catchment.

図 1. 研究地域の位置と試験流域での採水地点.

Table 1. Geographic information on the study catchment.

表1。試験流域の地理情報.

\begin{tabular}{ccccccc}
\hline $\begin{array}{c}\text { Sampling } \\
\text { point }\end{array}$ & $\begin{array}{c}\text { Altitude } \\
(\mathrm{m})\end{array}$ & $\begin{array}{c}\text { Longitudinal } \\
\text { distance }(\mathrm{km})\end{array}$ & $\begin{array}{c}\text { Catchment } \\
\text { area (ha) }\end{array}$ & $\begin{array}{c}\text { Plantation } \\
\text { area (ha) }\end{array}$ & $\begin{array}{c}\text { Plantation } \\
\text { ratio (\%) }\end{array}$ & $\begin{array}{c}\text { Streambed } \\
\text { gradient }\end{array}$ \\
\hline A & 34.0 & 0.55 & 29.3 & 10.2 & 34.8 & 0.37 \\
B & 18.0 & 0.40 & 36.6 & 15.1 & 41.3 & 0.09 \\
C & 9.5 & 0.24 & 40.0 & 16.7 & 41.8 & 0.05 \\
D & 5.0 & 0.15 & 42.0 & 17.5 & 41.6 & 0.05 \\
E & 3.0 & 0.02 & 44.3 & 19.5 & 44.0 & 0.01 \\
\hline
\end{tabular}

2002 年 9 月 10月（Low-flow season）及び2003年6月〜 7月（High-flow season）に中流域加下流域に分布する 掘抜き井戸(計13地点)において採水と水位の測定を行っ た。また，High-flow seasonには各井戸につき 3 ～4媣度 に分けて地下水を採水し, ポータブルメーター $(\mathrm{RM}-20 \mathrm{P}$, $\mathrm{DKK}$ ・ TOA）を用いて地下水の酸化還元電位（ORP）を 測定した。

採水した河川水, 地下水は実験窒に持ち㷌り, $5 \mathrm{mmol} \mathrm{L}^{-1}$ 硫酸を滴定用標準溶液とし, 指示薬としてメチルレッド ーブロムクレゾールグリーンを用い, $\mathrm{pH} 4.8$ アルカリ度硫 酸滴定法により $\mathrm{HCO}_{3}{ }^{-}$濃度を定量した。また, $0.20 \mu \mathrm{m}$ メ ンブランフィルターを用いて試料を濾過した後, $\mathrm{NO}_{3}{ }^{-}$,
$\mathrm{Cl}^{-}$濃度をイオンクロマトグラフ (HPLC, SHIMADZU) により定量した。なお， $\mathrm{NO}_{3}{ }^{-}-\mathrm{N}$ 濃度の定量下限は約 0.1 $\mathrm{mg} \mathrm{L} \mathrm{L}^{-1}$ である。

\section{結果亡考察}

河川水の流下にともなう $\mathrm{NO}_{3}{ }^{-}-\mathrm{N}$ 負荷量の変動

Fig. 2に，試験河川における平水時の流量 (a), 河川水 の $\mathrm{NO}_{3}{ }^{-}-\mathrm{N}$ 濃度 (b), 及び $\mathrm{NO}_{3}{ }^{-}-\mathrm{N}$ 負荷量 (c) の上流 ( $\mathrm{A}$ 地 点）から下流（E 地点）にかけての変動走示。 $\mathrm{NO}_{3}^{-}-\mathrm{N}$ 負荷量 $(F \mathrm{~N})$ は, 以下の式に示すように, 各採水地点に おいて観測された河川流量 $\left(Q_{\mathrm{r}}\right)$ と河川水の $\mathrm{NO}_{3}{ }^{-}-\mathrm{N}$ 濃度 
（CN）との積で算出した。

$$
F_{N}=Q_{r} C_{N}
$$

Fig. 2-aより, 全体的にみて流量は上流から中流に向かっ て増加し，その後下流で減少する傾向を示した。本流域 においては，中流域から河口に至るまで支流は存在せず， この区間は扇状地地形であり河川水面の標高が地下水面 の標高よりも高いことから，河川水が地下水へ涵養して いると考えられる。一方, $\mathrm{NO}_{3}{ }^{-}-\mathrm{N}$ 濃度に関しては, 流量 変化のように上流から下流にかけての一貫した傾向はみ られなかったが，流量が最も小さかった 10月において最 も濃度が高く，流量が多かった6月および 12 月において は比較的低濃度を示した（Fig. 2-b）。このことから，流 量が多い時期においては, 河川水中の $\mathrm{NO}_{3}{ }^{-}-\mathrm{N}$ が希釈され ていると考えられる。また, $\mathrm{NO}_{3}{ }^{-}-\mathrm{N}$ 負荷量は流量にほぼ 依存して变動し, 中流域で最も大きく, 下流に向かって 減少する傾向を示した（Fig. 2-c）。ここで，最下流の採 水地点 $\mathrm{E}$ で観測された $\mathrm{NO}_{3}{ }^{-}-\mathrm{N}$ 負荷量を河川からの $\mathrm{NO}_{3}{ }^{-}-\mathrm{N}$ 流出量であると仮定すると，(1) 式より平水時の平均流 出量は，1.04 $\mathrm{kg} \mathrm{N} \mathrm{d}^{-1}$ と見積もられる。本流域では，前述 したように中流域から下流にかけて河川水の地下水涵養 にともない $\mathrm{NO}_{3}{ }^{-}-\mathrm{N}$ 負荷量が減少していると推定される ことから，平水時においては，河川を経由して海洋一流 出する $\mathrm{NO}_{3}{ }^{-}-\mathrm{N}$ 量は比較的小さいと考えられる。

(a)

(b)

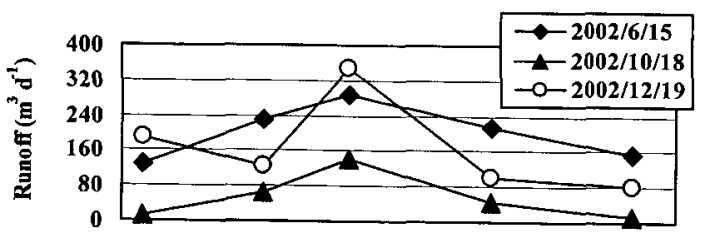

(c)
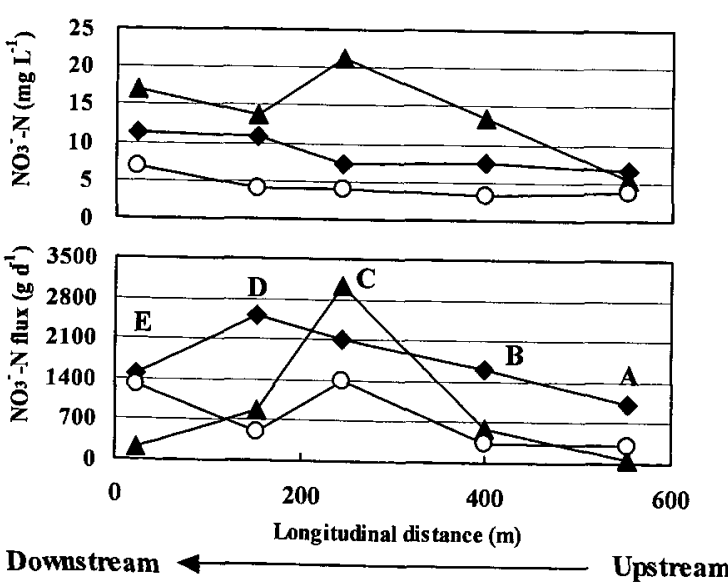

Fig. 2. Variations in: (a) runoff, (b) $\mathrm{NO}_{3}{ }^{-}-\mathrm{N}$ concentration, and (c) $\mathrm{NO}_{3}{ }^{-}-\mathrm{N}$ flux of river water with down flow.

図2。河川の流下にともなう (a) 河川流量，(b) 河川水の $\mathrm{NO}_{3}{ }^{-}-\mathrm{N}$ 濃度, (c) $\mathrm{NO}_{3}{ }^{-}-\mathrm{N}$ 負荷量の変動。
洪水流出時における河川からの $\mathrm{NO}_{3}{ }^{-}-\mathrm{N}$ 流出

Fig. 3 に2002年7月9〜10日にか忛て発生した降雨イ ベント時の降水量（a），及びC 地点における流量と河川 水の $\mathrm{NO}_{3}{ }^{-}-\mathrm{N}$ 濃度の時閒変化（b）を示す。また, Fig. 4に 河川が最も増水した 7 月 9 日の 21 時 50 分〜 22 時 03 分, 及 び平水時の流量 $(\mathrm{a}), \mathrm{NO}_{3}{ }^{-}-\mathrm{N}$ 濃度 $(\mathrm{b}), \mathrm{NO}_{3}{ }^{-}-\mathrm{N}$ 負荷量 (c) の上流から下流への変動を示す。平水時の変動につ いては, Fig. 2 に示した 3 回の調查結果の平均值を示す。 Fig. 3より, 採水地点Cでは降雨にともない流量は速やか に増加し, 対照的に $\mathrm{NO}_{3}{ }^{-}-\mathrm{N}$ 濃度は低下しており，他の採 水地点 (A, D, E) においても同様の傾向がみられた。ま た，Fig. 4-aより，降雨時はD地点で流量が最大となり， 平水時の約 70 倍に増加している。一方, $\mathrm{NO}_{3}{ }^{-}-\mathrm{N}$ 濃度は 平水時の約 $1 / 6$ に低下しており（Fig. 4-b), $\mathrm{NO}_{3}{ }^{-}-\mathrm{N}$ 負荷 量は，7月9日の 22 時にD地点で最大となり，平水時の約 16倍となっている（Fig. 4-c)。今回観測を行ったイベン トにおいては, 河川水中の $\mathrm{NO}_{3}{ }^{-}-\mathrm{N}$ が希粎されたため, 流 量の増加率に対し $\mathrm{NO}_{3}{ }^{-}-\mathrm{N}$ 負荷量の増加率が小さくなっ たと考えられる（Fig. 3，Fig. 4)。しかし，総雨量 $11 \mathrm{~mm}$ と小規模なイベントであったにも関わらず，約 10 時閒の イベント期間での総 $\mathrm{NO}_{3}{ }^{-}-\mathrm{N}$ 流出量は平水時約 4 日分に 相当した。一般的に，窒素成分については増水時期にお ける流出量が年閒流出量の大部分を占めることが知られ

(a)

(b)
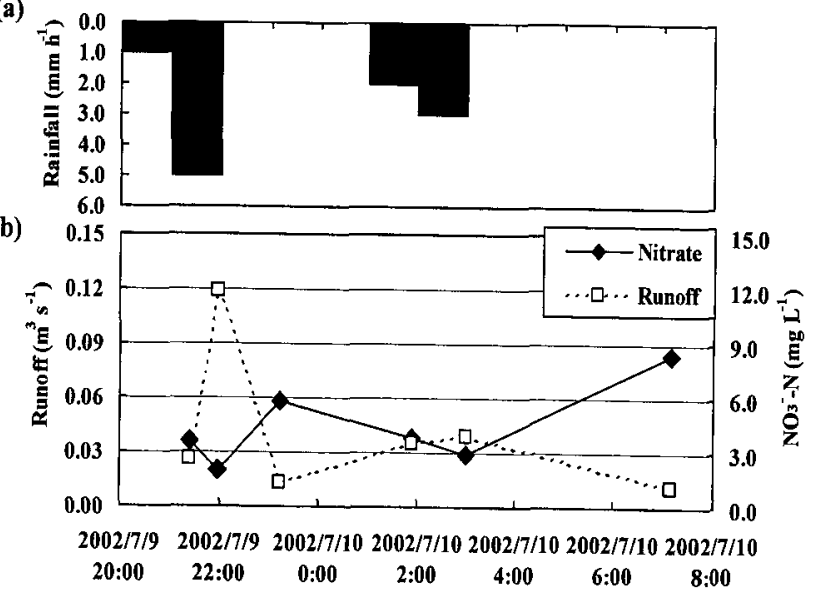

Fig. 3. Temporal variations in: (a) rainfall, (b) runoff and $\mathrm{NO}_{3}{ }^{-}-\mathrm{N}$ concentration during a rainfall event at site $\mathrm{C}$.

図3. 降雨イベント期間中の（a）降水量および（b）C地 点における河川流量と河川水の $\mathrm{NO}_{3}{ }^{-}-\mathrm{N}$ 濃度の変化. 


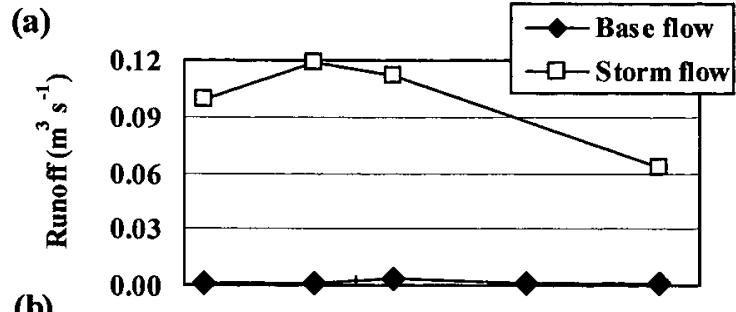

(b)

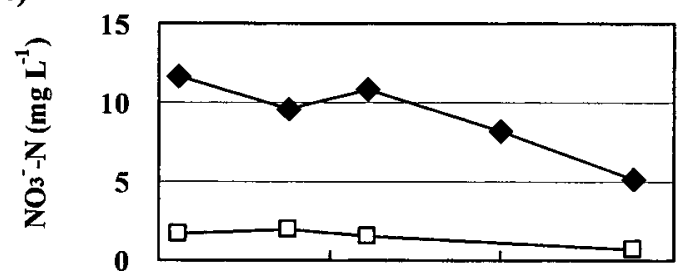

(c)

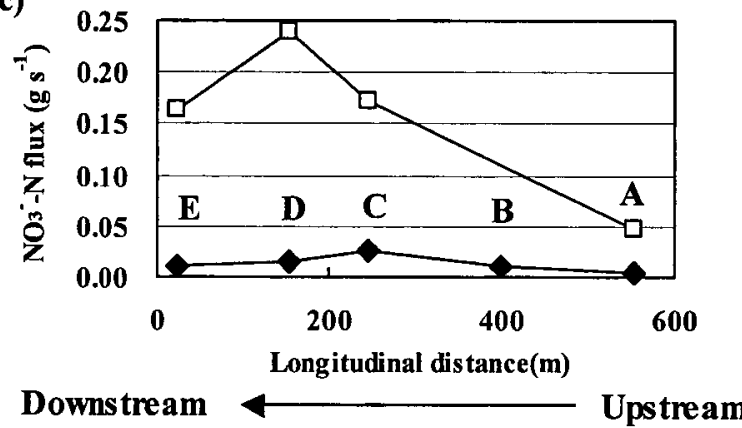

Fig. 4. Variations in: (a) runoff, (b) $\mathrm{NO}_{3}{ }^{-}-\mathrm{N}$ concentration, and (c) $\mathrm{NO}_{3}{ }^{-}-\mathrm{N}$ flux of river water with down flow at peak of rainfall event and at base flow.

図4. 降雨イベント期間中の河川流量ピーク時及び平水 時における (a) 河川流量, (b) 河川水の $\mathrm{NO}_{3}{ }^{-}-\mathrm{N}$ 濃 度，(c) $\mathrm{NO}_{3}{ }^{-}-\mathrm{N}$ 負荷量の流下にともなう変動。
て扝り（Burt et al., 1993），栄養塩類の流出は，まとまっ た降水量のイベント時に集中的に起こる（平田・村岡， 1988; Moldan and Cerny, 1994; 勝山ら，1998）ことも報告 されている。瀬戸内海沿岸地域は，前述したように年閒 を通じて降水量が非常に少なく，年間降水量の $50 \%$ 以上 が日降水量 $20 \mathrm{~mm}$ 以上のイベントで占められる(小野寺・ 成岡，2002）ことから，発生頻度の少ない大規模イベン 卜時の流出によって年閒流出量の大半が占められている 可能性がある。また, Fig. 4-aより，平水時には扇状地の ほぼ扇頂部にあたる C地点で流量が最大となるのに対し， イベント時はそれより一つ下流側の D 地点で最大となっ

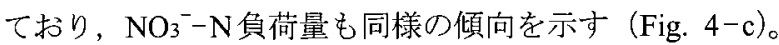
これは，降水や地表流などが河川人流入し，河川流量を 増加させたためであると考えられる。以上の結果から， 降雨イベント時には，河川を経由して直接海洋へ流出す る $\mathrm{NO}_{3}{ }^{-}-\mathrm{N}$ 量が増加し, 河川流出型の流出形態になると推 定される。

地下水による $\mathrm{NO}_{3}{ }^{-}-\mathrm{N}$ 流出

試験流域における 2002 年 9 月〜 10月（以下 Low-flow season）及び2003年 6 月〜7月（以下 High-flow season）の 地下水面図をFig. 5に示与。ここでは, 地下水面のポテン シャルを標高值で示す。また, Fig. 6に地下水の $\mathrm{NO}_{3}{ }^{-}-\mathrm{N}$ 濃 度分布図を示す。これらの結果から，本流域においては 全体的にみて地下水は山側から海側一流動しており（Fig. 5)，それにともない地下水の $\mathrm{NO}_{3}{ }^{-}-\mathrm{N}$ 濃度が減少する傾向 (a)

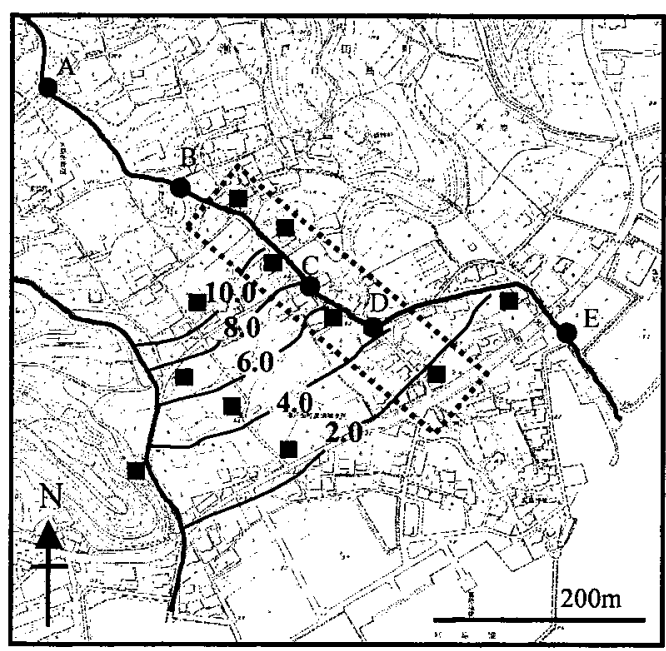

(b)

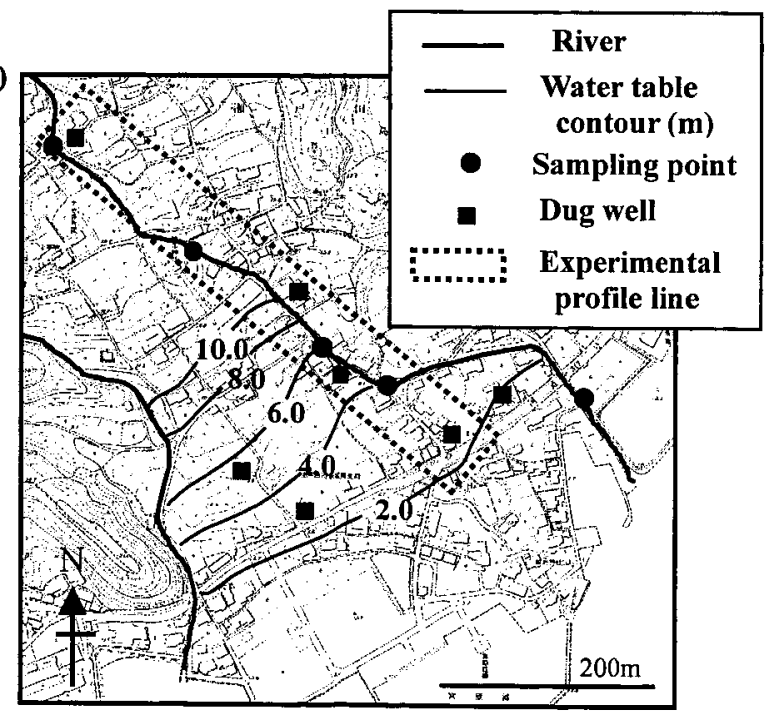

Fig. 5. Contour map of groundwater level in the study catchment: (a) low-flow season, (b) high-flow season. 図 5. 試験流域の地下水面分布図：（a）渇水期 (2002年9～10月), (b) 豊水期 $(2003$ 年 $9 \sim 10$ 月). 
(a)

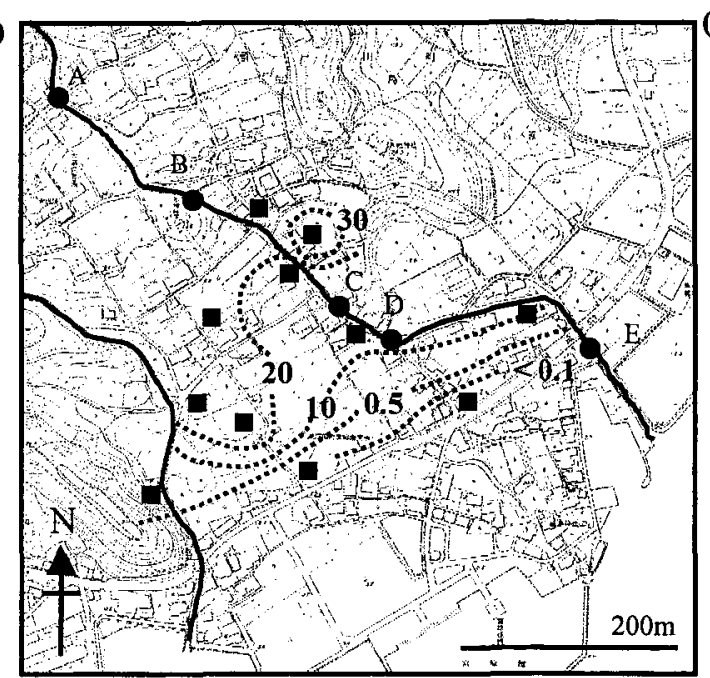

(b)

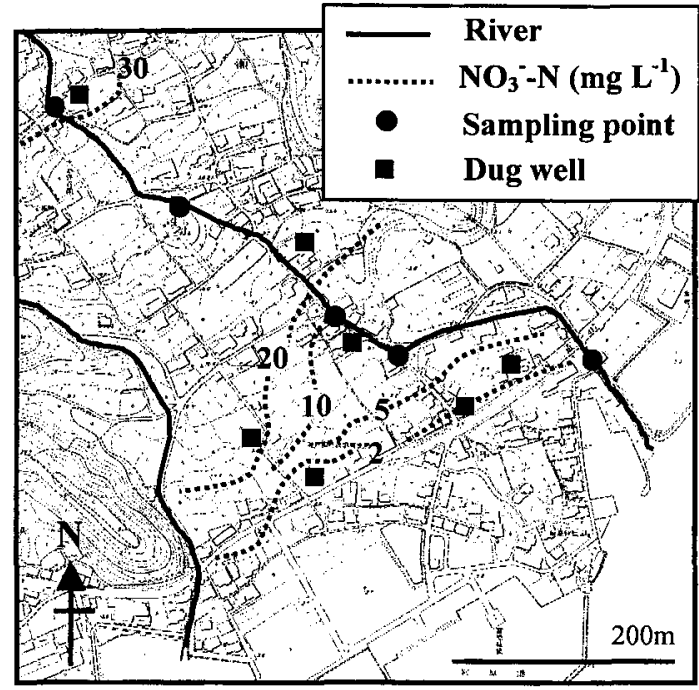

Fig. 6. Distribution of $\mathrm{NO}_{3}{ }^{-}-\mathrm{N}$ concentrations in groundwater: (a) low-flow season, (b) high-flow season. 図6. 地下水 $の \mathrm{NO}_{3}{ }^{-}-\mathrm{N}$ 濃度分布図 : (a) 渴水期 (2002年9 10月), (b) 豊水期 (2003 年9 10 月).

にあることが分かる（Fig. 6)。特に，Low-flow seasonに おいてはその変化が顕著であり, 中流域では約 $30 \mathrm{mg} \mathrm{L}^{-1}$ と噮境基隻 $\left(10 \mathrm{mg} \mathrm{L}^{-1}\right)$ をはるかに超える高濃度を示す が，最下流の井戸では $0.1 \mathrm{mg} \mathrm{L}^{-1}$ 以下となっている。ここ で，ダルシーの式（Darcy，1856）を用いて試騟流域にお ける地下水流量を算出し, 地下水の $\mathrm{NO}_{3}{ }^{-}-\mathrm{N}$ 濃度との積 から，地下水の $\mathrm{NO}_{3}{ }^{-}-\mathrm{N}$ 負荷量の見積もりを行う。ダル シーの式は以下のように示される。

$$
Q=K A\left(h l^{-} h_{2}\right) / l
$$

（2）式において， $Q$ は地下水流量， $K$ は透水係数， $A$ は 地下水の通過断面積, $l$ は地下水の流動距離, $h l-h z$ は $l$ の 区間に抢ける水理水頭損失示示（山本，1986）。最下流 部の井戸から海岸線までの平均動水勾配は, 潮位変動に ともなう変化を考慮しない場合, Low-flow seasonで 0.015 , High-flow seasonで 0.02 である。また，過去に行われた ボーリング井戸掘削時の地質データから，本流域では地 表から約 $20 \mathrm{~m}$ 下からは基盤であり，難透水層は分布して いないことから，不飽和帯の厚さを考慮し，带水層の厚 さをLow-flow (以下 LF) およびHigh-flow (以下 HF) seasonでそれぞれ $18 \mathrm{~m}, 19 \mathrm{~m}$ とした。また，下流部の流 域幅は約 $375 \mathrm{~m}$ であることから, 地下水の通過断断面積 $A$ は, $A L F=6750 \mathrm{~m}^{2}, A H F=7125 \mathrm{~m}^{2}$ となる。また，海岸 部で行った透水試験の結果から, 透水係数を $K=5.0 \times 10^{-3}$ $\sim 1.0 \times 10^{-2} \mathrm{~cm} \mathrm{~s}^{-1}$ の範囲内であるとした。ここで，地下 水位の季節変化より, Low-flowおよびHigh-flow seasonが 年間で半年ずつを占めているとし，地下水流出量 $Q_{L F} お$ よび $Q_{H F}$ を見積もった。 $K=1.0 \times 10^{-2} \mathrm{~cm} \mathrm{~s}^{-1}$ とした場合，
$Q_{L F}=364 \mathrm{~mm}, Q_{H F}=509 \mathrm{~mm}$ となり, 年間総流出量 $\left(Q_{L F}\right.$ $\left.+Q_{H F}\right)$ は $873 \mathrm{~mm}$ で年間降水量 $(1100 \mathrm{~mm})$ の約 $80 \%$ と見 積もられる。しかし，試験地域は比較的少雨であり，水 収支的に蒸発散量が降水量の $40 \%$ 以上を占好ると推定さ れる(塚本，1992）ことから，この值は妥当ではないと考 えられる。一方, $K=5.0 \times 10^{-3} \mathrm{~cm} \mathrm{~s}^{-1}$ とした場合は, $Q_{L F}$ $=182 \mathrm{~mm}, Q_{H F}=255 \mathrm{~mm}$ となり, 年間総流出量は $437 \mathrm{~mm}$ で年間降水量の約 $40 \%$ となり, 水収支的には妥当な值で あると考えられる。また，Fig. 6より，最下流の地下水の $\mathrm{NO}_{3}{ }^{-}-\mathrm{N}$ 濃度は，Low-flow およびHigh-flow seasonにお いてそれぞれ約 $0.1 \mathrm{mg} \mathrm{L}^{-1}$ ，約 $2.0 \mathrm{~m} \mathrm{~L}^{-1}$ であることから， （1）式上り，地下水による $\mathrm{NO}_{3}{ }^{-}-\mathrm{N}$ 流出量を見積もると， Low-flow㧍よびHigh-flow seasonにおいてそれぞれ 8.0 $\mathrm{kgN}, 224 \mathrm{kgN}$ となり，年閒で $232 \mathrm{kgN}$ と見積もられる。ま た, 調查地域の果樹園では年間約 $2400 \mathrm{~kg} \mathrm{ha}^{-1}$ の化学肥料 が散布されて抢り，肥料の成分を全て硫安（窒素含有率 約 $21 \%$ ) であると仮定すると, 窒素量は $504 \mathrm{~kg} \mathrm{ha}^{-1}$ となる。 また, 試験流域内の果樹園面積は 19.5 haであり (Table 1), 施肥による窒素インプット量は年間で $9828 \mathrm{kgN}$ と見積も られる。この結果から，地下水による年間 $\mathrm{NO}_{3}^{-}-\mathrm{N}$ 流出 量は, 果樹園起源の窒素インプット量のわずか $2.4 \%$ 程度 であるという計算になる。以上の結果をまとめたものを Table 2に示寸。本流域においては, 中流域では地下水の $\mathrm{NO}_{3}{ }^{-}-\mathrm{N}$ 濃度は高濃度を示すものの, 地下水が流域単位 での窒素流出に及ぼす影響は比較的小さいと推定された。 従来の研究の多くでは, 地下水による海洋への窒素流出 量惊さくないと見積もられていたが（Johannes, 1980； 
沿岸局状地における硝酸性窒素流出

Table 2. Groundwater discharge and $\mathrm{NO}_{3}{ }^{-}-\mathrm{N}$ discharge by groundwater.

表 2. 試験流域における地下水流出量および地下水による掌素流出量.

\begin{tabular}{|c|c|c|c|}
\hline & $\begin{array}{c}\text { Groundwater } \\
\text { discharge }(\mathrm{mm})\end{array}$ & $\begin{array}{c}\mathrm{NO}_{3}{ }^{-}-\mathrm{N} \text { discharge } \\
(\mathrm{kgN})\end{array}$ & $\begin{array}{c}\mathrm{NO}_{3}{ }^{-}-\mathrm{N} \text { discharge } \\
\text { ratio }(\%)\end{array}$ \\
\hline $\begin{array}{l}\text { Low-flow season } \\
\quad(6 \text { months })\end{array}$ & 182 & 8.0 & 0.08 \\
\hline \multirow{2}{*}{$\begin{array}{c}\text { High-flow season } \\
\text { (6 months) } \\
\text { Total } \\
(1 \text { year })\end{array}$} & 255 & 224 & 2.28 \\
\hline & 437 & 232 & 2.36 \\
\hline
\end{tabular}

Zektser and Loaiciga, 1993), 本研究では異なる結果を得た。 また，Low-flowおよびHigh-flow seasonともに，下流 域において $\mathrm{NO}_{3}{ }^{-}-\mathrm{N}$ 濃度の急激な減少がみられたことか ら (Fig. 6), 地下水中で何らかの形で $\mathrm{NO}_{3}{ }^{-}-\mathrm{N}$ が除去され ている可能性が考えられる。従来から流出域ないし地下 水流動にともない地下水の $\mathrm{NO}_{3}{ }^{-}-\mathrm{N}$ 濃度が低下寸るとい う例がいくつか報告されており（Howard，1985; Postma et al., 1991; 石塚・小野寺, 1997), これらの現象は，いず れも脱窒反応によるものであると説明されている。鶴巻 （1989）は，脱窒反応を以下のように示している。

$4 \mathrm{NO}_{3}{ }^{-}+5 \mathrm{CH}_{2} \mathrm{O}+4 \mathrm{H}^{+} \rightarrow 2 \mathrm{~N}_{2}+5 \mathrm{CO}_{2}+7 \mathrm{H}_{2} \mathrm{O}$

また, Trudell et al., (1986) による脱窒の反応式は以下 のようである。

$$
\begin{aligned}
4 \mathrm{NO}_{3}{ }^{-} & +5 / 6 \mathrm{C}_{6} \mathrm{H}_{12} \mathrm{O}_{6}+5 \mathrm{CaCO}_{3}+4 \mathrm{H}^{+} \\
& \rightarrow 2 \mathrm{~N}_{2}+10 \mathrm{HCO}_{3}{ }^{-}+5 \mathrm{Ca}^{2+}+2 \mathrm{H}_{2} \mathrm{O}
\end{aligned}
$$

生物化学的脱窒は, 嫌気的環境下で有機物が存在する 場合, 微生物により $\mathrm{NO}_{3}{ }^{-}$及び $\mathrm{NO}_{2}{ }^{-}$が還元され, $\mathrm{N}_{2}$ となっ て大気中に放出される反応である。また，(4) 式におい ては反応が進行すると $\mathrm{HCO}_{3}{ }^{-}$濃度が高くなることが示さ れており, 脱窒が $\mathrm{HCO}_{3}{ }^{-}$濃度の増加要因の一つであるこ とを示す。Fig. 7にFig. 5 中の Experimental profile line上に 分布する井戸について, 地下水流動にともなう $\mathrm{NO}_{3}{ }^{-}-\mathrm{N}$, $\mathrm{HCO}_{3}{ }^{-}-\mathrm{C}, \mathrm{Cl}^{-}$濃度の変化を示す。 $\mathrm{Cl}^{-}$濃度は下流域で比 較的高い傾向にあり，特にLow-flow season においては 最下流で $133 \mathrm{mg} \mathrm{L}^{-1}$ と高濃度を示す（Fig. 7-a）。しかし， 地下水と同時期に採水した海水の $\mathrm{Cl}^{-}$濃度は約 $20000 \mathrm{mg}$ $\mathrm{L}^{-1}$ であり，海水寄与率を算出するとわずか $0.7 \%$ 程度で あることから， $\mathrm{NO}_{3}{ }^{-}-\mathrm{N}$ の消失は海水の希粎作用のみで は説明できないと考えられる。一方で, $\mathrm{HCO}_{3}{ }^{-}-\mathrm{C}$ 濃度 は $\mathrm{NO}_{3}{ }^{-}-\mathrm{N}$ 濃度と対照的に下流域で高濃度を示すことか ら (Fig. 7-a, b), 脱窒反応が起こっている可能性が示唆 される(式4)。また，Fig. 8にHigh-flow seasonにおける中 流域から下流域にかけての地下水の酸化還元電位 (ORP)
の分布を示す。なおここで用いたのは標準水素電極に 対する電位である。この図より，下流域における ORP值 は100〜200 mVと相対的に低い傾向を示すが, 完全な還 元状態ではないことが分かる。しかし，従来の研究にお いて，土壌中では空隙率が $20 \%$ 以下（飽和領域が $80 \%$ 以 上）になると有意な脱窒反応が起こることが明らかにさ れており（Stewart, 1992)，下流域では，脱窒が起こりう る環境が形成されていると考えられる。

以上の結果をまとめた概念図として Fig. 9 を示す。平 水時は, 中流域から下流域に向かって河川水の地下水溷 養にともない河川流量が減少し, それに依存して $\mathrm{NO}_{3}{ }^{-}-\mathrm{N}$ 負荷量も減少した。このため, 河川から海洋への $\mathrm{NO}_{3}{ }^{-}-\mathrm{N}$

(a)

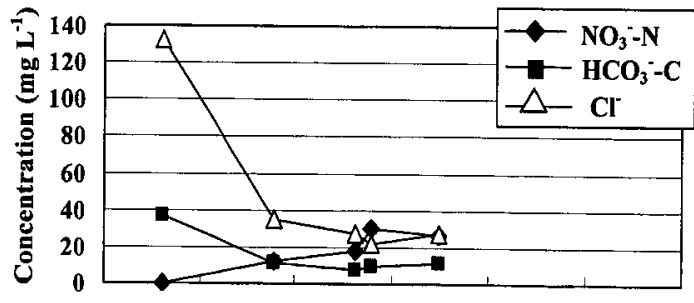

(b)

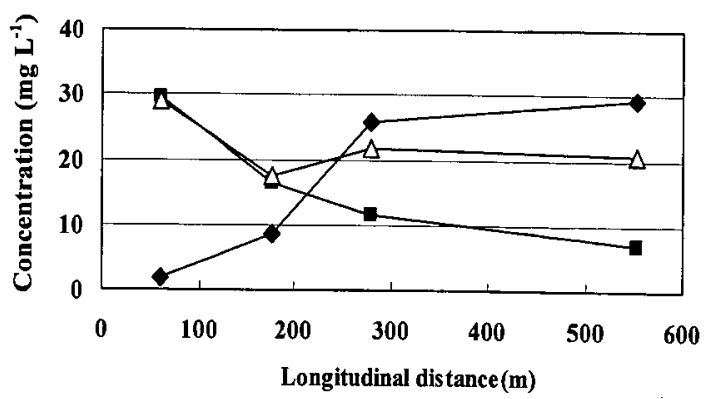

Fig. 7. Variations in $\mathrm{NO}_{3}{ }^{-}-\mathrm{N}, \mathrm{HCO}_{3}{ }^{-}-\mathrm{C}^{-}$and $\mathrm{Cl}^{-}$concentrations with groundwater flow: (a) low-flow season, (b) highflow season.

図 7. 地下水流動にともなう地下水中の $\mathrm{NO}_{3}{ }^{-}-\mathrm{N}, \mathrm{HCO}_{3}{ }^{-}-\mathrm{C}$ および $\mathrm{Cl}^{-}$濃度変化: (a) 渴水期 (2002 年9〜10月), (b) 豊水期（2003年 6〜 7月）. 


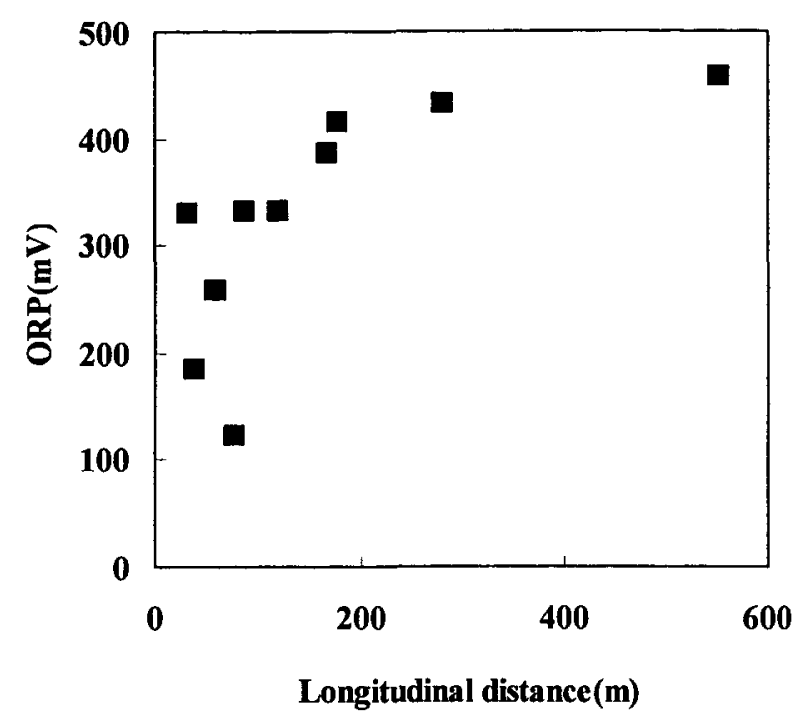

Fig. 8. Distribution of ORP in groundwater. 図8. 地下水の酸化還元電位の分布.

流出量は比較的小さいと考光られ, なおかつ下流域の地 下水中では $\mathrm{NO}_{3}{ }^{-}-\mathrm{N}$ 濃度が減少したことから, 流域単位で の $\mathrm{NO}_{3}{ }^{-}-\mathrm{N}$ 流出量は比較的小さいと見積もられる (Fig. 9-a)。一方, 降雨イベント時は河川流量の増加にともない $\mathrm{NO}_{3}{ }^{-}-\mathrm{N}$ は河川流出型となるため, 流域単位での $\mathrm{NO}_{3}{ }^{-}-\mathrm{N}$ 流出量は平水時と比較して格段に大きくなると考えられ る(Fig. 9-b)。

\section{まとめ}

本研究では，果樹園の分布する局状地小流域において 陸域から海洋への $\mathrm{NO}_{3}{ }^{-}-\mathrm{N}$ 流出過程を明らかにすること を目的とし，河川水と地下水の採水，河川流量の測定お よび採取した水試料についての $\mathrm{NO}_{3}{ }^{-}-\mathrm{N}, \mathrm{HCO}_{3}{ }^{-}-\mathrm{C}, \mathrm{Cl}^{-}$ の定量分析を行った。その結果は，以下のようである。

1) 平水時における河川水の $\mathrm{NO}_{3}{ }^{-}-\mathrm{N}$ 負荷量は, 中流域か ら下流域の扇状地において河川の失水にともない減少 した。またここの傾向は 3 回の観測において同様に確 認された。したがって，平水時における河川からの $\mathrm{NO}_{3}{ }^{-}-\mathrm{N}$ 流出量は比較的小さいと見積もられた。

2) 降雨イベント時は, 流量の増加にともない $\mathrm{NO}_{3}{ }^{-}-\mathrm{N}$ 負

\section{a) Base flow period}

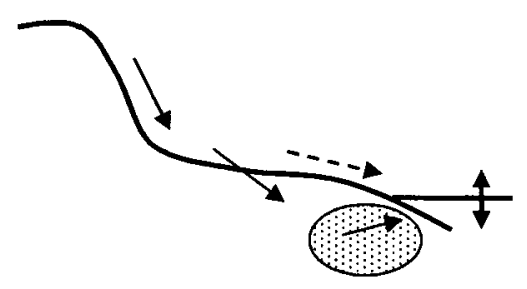

b) Storm flow period

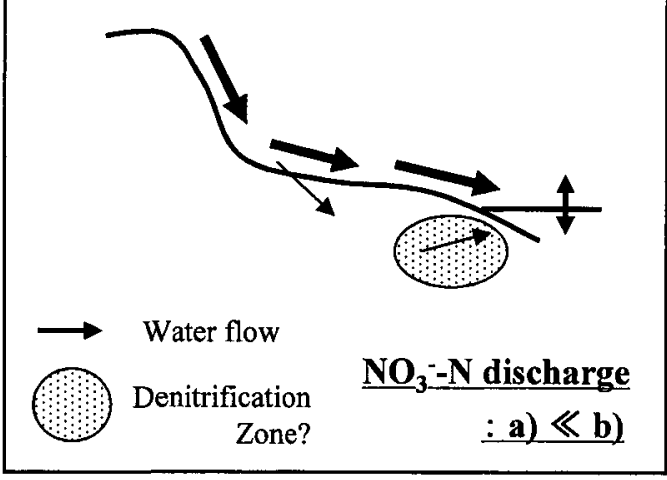

Fig. 9. Schematic diagram of $\mathrm{NO}_{3}{ }^{-}-\mathrm{N}$ transport process in the study catchment.

図9. 試験流域における $\mathrm{NO}_{3}{ }^{-}-\mathrm{N}$ 流出過程の模式図.

荷量が増加し，ピーク時で平水時の約 16 倍に達した。 また，イ心゙ント全体を通しては， $\mathrm{NO}_{3}{ }^{-}-\mathrm{N}$ 流出量が平 水時約 4 日分の量に相当した。このことから，流域に 扮ける $\mathrm{NO}_{3}{ }^{-}-\mathrm{N}$ 流出形態が，降雨時には河川流出型と なることが明らかになった。

3)地下水の $\mathrm{NO}_{3}{ }^{-}-\mathrm{N}$ 濃度は, 中流域では $20 \mathrm{mg} \mathrm{L}^{-1}$ 以上の 比較的高濃度を示したものの, 下流域では $2.0 \mathrm{mg} \mathrm{L}^{-1}$ 以下にまで低下した。結果として, 地下水による海洋 への $\mathrm{NO}_{3}{ }^{-}-\mathrm{N}$ 流出量は, 肥料起源の年間窒素インプット 量のわずか $2 \%$ 程度であると見積もられた。また, 地 下水の $\mathrm{HCO}_{3}{ }^{-}-\mathrm{C}$ 濃度および ORP の変化から, 下流域 において生物化学的脱窒反忘による $\mathrm{NO}_{3}{ }^{-}-\mathrm{N}$ の除去が 起こっている可能性が示唆された。

\section{謝辞}

本研究は，文部科学省科学研究費補助金基盤研究 A (2) 「瀬戸内流域における自然物質循環速度を考慮した環境 劣化の影響評価一岩石一水一生物相互作用の速度論的 解析一」(課題番号: 13308030, 代表者: 福岡正人) によ る研究成果の一部である。また，本研究を行うにあたり， 
広島大学総合科学部開發一郎教授, 福岡正人教授および 成岡朋弘氏（当時, 広島大学生物圈科学研究科院生）に は貴重な御助言をいただいた。また，広島県瀬戸田町の 住民の皆様および瀬戸田町役場の職員の方々には現地調 査にご協力いただき，多くの便宜を図っていただいた。 以上を記し，媣く感謝の意を表します。

\section{文献}

Böhlke, J. K. and J. M. Denver (1995) : Combined use of groundwater dating, chemical, and isotopic analyses to resolve the history and fate of nitrate contamination in two agricultural watersheds, Atlantic coastal plain, Maryland. Water Resources Research, 31: 2319-2339.

Burt, T. P., A. L. Heathwaite and S. T. Trudgill (1993): Nitrate; Processes, Patterns and Management. John Wiley $\&$ Sons Press, Chichester.

Capone, D. G. and M. F. Bautista (1985) : A groundwater source of nitrate in nearshore marine sediments. Nature, 313: 214-216.

Darcy, H. P. G.(1856) : Les Fontaines Publiques de la Ville de Dijon. Dalmont Press, Paris.

D'Elia, C. F., K. L. Webb and J. W. Porter (1981) : Nitrate-rich groundwater inputs to Discovery Bay, Jamaica: A significant source of $\mathrm{N}$ to local reefs? Bulletin of Marine Science, 31: 903-910.

海老瀬潜一 (1981) : 霞ヶ浦流入河川の流出負荷量変化 とその評価（陸水域の富栄養化に関する総合研究，V). 国立公害研究所研究報告, $21,130 \mathrm{pp}$.

海老瀬潜一 (1985)：降雨による士壤層加ら河川への $\mathrm{NO}_{3}{ }^{-}$の排出. 衛生工学研究論文集, 21: 48-59.

Hewlett, J. D. (1964) : Principles of Forest Hydrology. The University of Georgia Press, Georgia.

平田健正・村岡浩爾 (1988)：森林域における物質循環特 性の渓流水質に及ぼ寸影響. 土木学会論文集, 399: 131-140.

Howard, K. W. F. (1985) : Denitrification in a major limestone aquifer. Journal of Hydrology, 76: 265-280.

池上佳志 - 中越信和 (1995) : 広島県瀬戸田地区の景観構 造. 広島大学総合科学部紀要IV理系編, 21: 131-144.

石塚成宏・小野寺真一 (1997): $\delta^{15} \mathrm{~N}$ 值による平地林浅層 地下水中における脱窒の検証一茨城県南西部常総台地 の例. 日本土壤肥料科学雑誌, 68: 1-7.

Johannes, R. E. (1980) : The ecological significance of the submarine discharge of groundwater. Marine Ecology Progress Series, 3: 365-373.

勝山正則・大手信人・浅野友子・小橋澄治 (1998): 森林 流域からの流出水質に降雨イベントが影響を与えるメ カニズム. 京都大学農学部附属演習林報告, 69:26-37. 環境省 (2003)：環境白書. 株式会社ぎょうせい, 東京. 熊沢喜久雄 (1994）：環境保全型農業における土壌肥料研
究の展望. 環境保全型農業シンポジウム「暖地農業にお ける養分循環の問題点上技術的展望」, 第 12 回土・水研 究会: 1-16.

Marsh, J. A. and Jr. (1977): Terrestrial inputs of nitrogen and phosphates on fringing reefs on Guam. Proceedings of 3rd International Coral Reef Symposium: 331-336.

McLachlan, A. and W. Illenberger (1986) : Significance of groundwater nitrogen input to a beach/surf zone ecosystem. Stygologia, 2: 291-296.

Moldan, B. and J. Cerny (1994) : Biogeochemistry in Small Catchments. John Wiley \& Sons Press, Chichester.

Nakagoshi, N. and Y. Ohta (1992): Factors affecting the dynamics of vegetation in the landscapes of Shimokamagari Island, southwestern Japan. Landscape Ecology, 7: 111-119. 中兽根英雄・中村良太 (1984): 降雨時に扔ける烏川の水 質変動と污濁負荷量の流出について，農業土木学会論 文集, 111: 35-42.

小野寺真一・成岡朋弘 (2002): 広島県瀬戸内海沿岸域の 降雨特性一降雨時閒帯, 季節性, 降雨強度一。広島大 学総合科学部紀要IV理系編, 28: 61-68.

Postma, D., C. Boesen, H. Kristiansen and F. Larsen (1991): Nitrate reduction in an unconfined sandy aquifer : water chemistry, reduction processes, and geochemical modeling. Water Resources Research, 27: 2027-2045.

Simmons, G. M. and Jr. (1992) : Importance of submarine groundwater discharge (SGWD) and seawater cycling to material flux across sediment/water interfaces in marine environments. Marine Ecology Progress Series, 84:173-184. 宗宮 功 (1993): 自然の浄化機構. 技報堂出版, 東京.

Stewart, B. A. (1992): Advances in Soil Science, vol.18. Springer-Verlag Press, New York.

竹内 誠 (1995): 流域におうける水質保全機能の評価．農 林交流センターシンポジウム「農耕地における浅層地 下水等の污染状況と今後の対策」: 87-114.

谷口澄夫 (1978) : 瀬戸内の風土と歴史, 後藤陽一・石田 寛 (編著)：295-297. 山川出版社, 東京.

田瀬則雄 (2003) : 硝酸 - 亜硝酸窒素污染対策の展望. 水環 境学会誌, 26: 546-550.

Trudell, M. R., R.W. Gillham and J. A. Cherry (1986) : An in-situ study of the occurrence and rate of denitrification in a shallow unconfined sand aquifer. Journal of Hydrology, 83: $251-268$.

塚本良則 (1992): 森林水文学. 文永堂出版, 東京.

鶴巻道二 (1989): 地下水の挙動を水質から診る一地盤を 観る・視る・診る、中世古幸次郎教授退官記念論文集： 29-45.

鶴巻道二 (1992) : 浅層地下水の硝酸性窒素. 地下水学会 誌, 34: 153-162.

Uchiyama, Y., K. Nadaoka, P. Rölke, K. Adachi and H. Yagi (2000) : Submarine groundwater discharge into the sea and associated nutrient transport in a sandy beach. Water Resources 


\section{齋藤光代ら}

Research, 36: 1467-1479.

山本荘毅 (1986) : 地下水学用語辞典. 古今書院, 東京.

Zektser, I. S. and H. G. Loaiciga (1993) : Groundwater fluxes

in the global hydrologic cycle: past, present and future.

Journal of Hydrology, 144: 405-427. 